

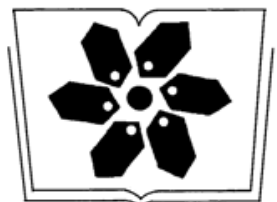

中国科学院科学出版基金资助出版
生 态 学 报

(SHENGTAI XUEBAO)

第 33 卷第 19 期 2013 年 10 月 (半月刊)

中国生态学学会 2013 年学术年会专辑 卷首语

生态系统服务研究文献现状及不同研究方向评述。 马凤娇, 刘金铜, A. Egrinya Eneji (5963) 非人灵长类性打摚行为研究进展 杨斌,王程亮,纪维红,等 (5973) 密度制约效应对啮齿动物繁殖的影响 . 韩群花, 郭 聪, 张美文 (5981) 食物链长度远因与近因研究进展综述 王玉玉,徐军,雷光春 (5990) $\mathrm{AM}$ 真菌在植物病虫害生物防治中的作用机制 罗巧玉，王晓娟，李媛媛，等 (5997) 保护性耕作对农田碳、氮效应的影响研究进展 . 薛建福, 赵 荃金, Shadrack Batsile Dikgwatlhe, 等 (6006) 圈养大熊猫野化培训期的生境选择特征 张明春,黄炎,李德生,等 (6014) 利用红外照相技术分析野生白冠长尾雉活动节律及时间分配 赵玉泽, 王志臣,徐基良,等 (6021) 风速和持续时间对树麻雀能量收支的影响 杨志宏, 吴庆明, 董海燕, 等 (6028) 白马雪山自然保护区灰头小舀鼠的巢址特征 李艳红, 关进科,黎大勇,等 (6035) 生境片段化对千岛湖岛屿上黄足厚结猛蚁遗传多样性的影响 罗媛媛, 刘金亮, 黄杰灵, 等 (6041) 基于 $28 \mathrm{~S}$, COI 和 Cytb 基因序列的薜荔和爱玉子传粉小蜂分子遗传关系研究

吴文珊, 陈友铃, 孙伶俐, 等 (6049) 高榕榕果内 Eupristina 属两种榕小蜂的遗传进化关系 陈友铃, 孙伶例, 武蕾蕾, 等 $(6058)$ 镉胁迫下杞柳对金属元素的吸收及其根系形态构型特征 王树风, 施翔, 孙海菁, 等 (6065) 邻苯二甲酸对萝卜种子萌发、幼苗叶片膜脂过氧化及渗透调节物质的影响

杨延杰, 王晓伟, 赵 康, 等 (6074)

极端干旱区多枝柽柳幼苗对人工水分干扰的形态及生理响应 马晓东, 王明慧, 李卫红, 等 (6081) 贝壳砂生境酸柬叶片光合生理参数的水分响应特征..... 王荣荣,夏江宝,杨吉华,等 (6088) 陶粒覆盖对土壤水分、植物光合作用及生长状况的影响..... 谭雪红, 郭小平, 赵廷宁 (6097) 不同林龄短枝木麻黄小枝单宁含量及养分再吸收动态..... 叶功富, 张尚炬, 张立华,等 (6107)

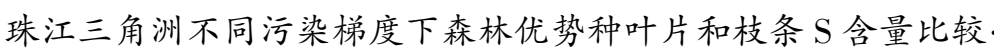
裴男才, 陈步峰, 邹志谨, 等 (6114) $\mathrm{AM}$ 真菌和磷对小马安羊蹄甲幼苗生长的影响 宋成军,曲来叶,马克明, 等 (6121) 盐氮处理下盐地碱蓬种子成熟过程中的离子积累和种子萌发特性............... 周家超,付婷婷, 赵维维,等 (6129) $\mathrm{CO}_{2}$ 浓度升高条件下内生真菌感染对宿主植物的生理生态影响 师志冰, 周 勇, 李 夏, 等 $(6135)$ 预处理方式对香蒲和芦苇种子萌发的影响 孟 焕,王雪宏,佟守正,等 (6142) 镉在土壤-金丝垂柳系统中的迁移特征 雯, 魏 虹, 孙晓灿, 等 (6147) 马尾松人工林近自然化改造对植物自然更新及物种多样性的影响........ 罗应华,孙冬婧,林建勇,等 (6154) 濒危海草贝克喜盐草的种群动态及土壤种子库 以广西珍珠湾为例……

邱广龙,范航清,李宗善,等 (6163)

毛乌素沙地南缘沙丘生物结皮对凝结水形成和蒸发的影响 尹瑞平, 吴永胜, 张 欣, 等 (6173) 塔里木河上游灰胡杨种群生活史特征与空间分布格局…… 韩 路, 席琳乔, 王家强, 等 (6181)

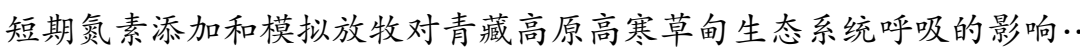
宗宁, 石培礼, 蔣 婧, 等 (6191) 松嫩平原微地形下土壤水盐与植物群落分布的关系 杨 帆,王志春,王云贺,等 (6202) 
广州大夫山雨季林内外空气 TSP 和 $\mathrm{PM}_{2.5}$ 浓度及水溶性离子特征 马鞍列岛岩礁生境鱼类群落结构时空格局…… 黄海细纹狮子鱼种群特征的年际变化. 三种温带森林大型土壤动物群落结构的时空动态 笔管榕榕小蜂的群落结构与物种多样性 海洋生态资本理论框架下的生态系统服务评估 中国地貌区划系统一以自然保护区体系建设为目标..... 生态植被建设对黄土高原农林复合流域景观格局的影响 华北农牧交错带农田-草地景观镶嵌体土壤水分空间异质性 中国北方春小麦生育期变化的区域差异性与气候适应性 中国南方喀斯特石漠化演替过程中土壤理化性质的响应 气候变化对东北沼泽湿地潜在分布的影响…… 内蒙古不同类型草地土壤氮矿化及其温度敏感性 黑河中游荒漠绿洲区土地利用的土壤养分效应 成都平原北部水稻土重金属含量状况及其潜在生态风险评价 大西洋中部延绳钓黄鯺金枪鱼渔场时空分布与温跃层的关系

夏季台湾海峡南部海域上层水体的生物固氮作用 北长山岛森林乔木层碳储量及其影响因子

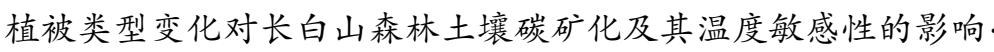
油松遗传结构与地理阻隔因素的相关性 ... 基于辅助环境变量的土壤有机碳空间插值 以黄土丘陵区小流域为例
肖以华, 李昫, 旷远文, 等 (6209) 汪振华, 赵 静, 王 凯, 等 (6218) 陈云龙, 单秀娟, 周志鹏, 等 (6227) . 李 娜, 张雪萍, 张利敏 (6236) 陈友铃, 陈晓倩, 吴文珊, 等 (6246) 陈 尚, 任大川, 夏 涛, 等 (6254) . 郭子良, 崔国发( 6264) 易扬, 信忠保, 覃云斌, 等 (6277) 王红梅, 王仲良, 王 壁, 等 (6287) 俄有浩, 霍治国, 马玉平, 等 (6295) ... 盛茂银, 刘洋, 熊康宁 (6303) 贺伟, 布仁仓, 刘宏娟, 等 (6314) 朱剑兴, 王秋风, 何念鹏, 等 (6320) 马志敏, 吕一河, 孙飞翔, 等 (6328) 秦鱼生, 喻华, 冯文强, 等 (6335) 杨胜龙, 马军杰, 张禹, 等 (6345) 林 峰, 陈 敏, 杨伟锋, 等 (6354) 石洪华, 王晓丽, 王 嫒, 等 (6363) 王丹, 吕瑜良, 徐 丽, 等 (6373) 孟翔翔, 狄晓艳, 王孟本, 等 (6382)

文 雯, 周宝同, 汪亚峰, 等 (6389)

基于生命周期视角的产业资源生态管理效益分析一以虚拟共生网络系统为例

施晓清,李笑诺,杨建新 (6398)

生态脆弱区贫困与生态环境的博弯分析 祁新华, 叶士琳, 程 暗, 等 (6411)

“世博”背景下上海经济与环境的耦合演化 倪 尧, 岳文泽, 张云堂, 等 $(6418)$

期刊基本参数: CN 11-2031/Q * $1981 * \mathrm{~m} * 16 * 464 * \mathrm{zh} * \mathrm{P} * ¥ 90.00 * 1510 * 55 * 2013-10$

封面图说: 毛乌素沙地南缘沙丘的生物结皮一一生物土壤结皮广泛分布于干旱和半干旱区, 它的形成和发育对荒漠生态系统 生态修复过程产生重要的影响。组成生物结皮的藻类、苔藓和地衣是常见的先锋植物, 它们不仅能在严重干旱缺 水、营养贫㾑恶劣的环境中生长、繁殖, 并且能通过其代谢方式影响并改变环境。其中一个重要的特点是, 生物结皮 表面的凝结水显著大于裸沙。研究表明, 凝结水是除降雨之外最重要的水分来源之一, 在水分极度匮乏的荒漠生态 系统, 它对荒漠生态系统结构、功能和过程的维持产生着重要的影响。

彩图及图说提供: 陈建伟教授 北京林业大学 E-mail: cites.chenjw@163.com 


\title{
中国南方喀斯特石漠化演替过程中 土壤理化性质的响应
}

\author{
盛茂银 ${ }^{1,2}$, 刘 洋 ${ }^{1}$, 熊康宁 ${ }^{1,2}$, * \\ （1. 贵州师范大学中国南方喀斯特研究院,贵阳 550001;2. 贵州省喀斯特山地生态环境国家重点实验室培育基地,贵阳 550001)
}

\begin{abstract}
摘要: 以中国西南典型喀斯特石漠化生态系统土壤为研究对象,运用野外定点取样和实验室分析检测方法,研究不同等级石漠 化环境土壤理化性质特征; 运用空间代替时间方法,探讨石漠化演替过程中土壤理化性质的响应及其机制, 旨在为中国西南喀 斯特森林生态保护和石漠化生态系统恢复重建提供理论支撑。结果表明: 1) 不同等级石漠化环境土壤理化性质存在显著差 异, 土壤容重、毛管孔隙度、总孔隙度、田间含水量、毛管含水量、 $\mathrm{pH}$ 值、有机质、水解氮、有效磷和全钾均在不同等级石漠化环境 间具有显著差异。但这些指标并不是随着石漠化程度增加而一直退化,而是一个先退化后改善的趋势;2) 土壤有机质、氮素、 毛管持水量、容重和孔隙度与土壤其它绝大多数理化因子具有明显的相关性,是土壤理化性质的关键因子,在改善土壤理化性 质和促进养分循环方面起着关键作用; 3 ) 主成分分析也表明,土壤有机质、氮素、钾素、容重、持水状况、孔隙度等是基于土壤理 化性质评价石漠化程度的关键指标。作者提出了强度石漠化环境裸岩对土壤养分的聚集效应学说和喀斯特石漠化演替过程中 土壤理化性质的响应及其机制。研究结果对中国西南喀斯特森林生态保护和石漠化生态系统恢复重建具有重要的理论意义和 实践指导价值。
\end{abstract}

关键词: 喀斯特;石漠化;土壤理化性质;演变规律;机制

\section{Response of soil physical-chemical properties to rocky desertification succession in South China Karst}

\author{
SHENG Maoyin ${ }^{1,2}$, LIU Yang ${ }^{1}$, XIONG Kangning ${ }^{1,2, *}$ \\ 1 Institute of South China Karst, Guizhou Normal University, Guiyang 550001, China \\ 2 State Key Laboratory Incubation Base for Karst Mountain Ecology Environment of Guizhou Province, Guiyang 550001, China
}

\begin{abstract}
Karst rocky desertification has been an important ecological issue hindering the economy and society development of South China Karst region, and the control of rocky desertification has been clearly listed in the national projects of economy and society development. But there are short of soil researches in karst rocky desertification ecosystem, and the succession of soil physical-chemical properties is still unclear in the process of rocky desertification, which hardly hinders the control of rocky desertification well work.

Based on these problems, in this study, firstly, three typical rocky desertification regions, that is, Yachi, Hongfenghu, and Huajiang of Guizhou Province, representing three different typical karst landforms of plateau mountain, plateau basin, and plateau gorge, respectively, were selected as experiment areas, and 45 sample plots with area of $20 \mathrm{~m} \times$ $20 \mathrm{~m}$, respectively, were set up for the 5 typical degrees of rocky desertification, that is, no, potential, low, middle, and high, in these three experimental areas. Then, the soil physical-chemical properties were surveyed and analyzed by the methods of chemical determination and mathematical statistics. Results show that 1 ) there are obvious differences of soil physical-chemical properties between different degrees of rocky desertification, specifically, bulk density, capillary
\end{abstract}

基金项目:国家“十二五”科技支撑计划重大课题(2011BAC09B01) ; 贵州师范大学博士科研启动基金(2012)

收稿日期: 2013-05-08; 修订日期: 2013-07-29

* 通讯作者 Corresponding author.E-mail: shmoy@163.com 
porosity, total porosity, field moisture capacity, capillary moisture capacity, pH, organic matter content, hydrolysis nitrogen content, available phosphorus content, and total potassium content. But, not as expected, the soil degeneration do not always raise with the increased degree of rocky desertification. In fact, with the increased degree of rocky desertification, the soil degenerate firstly and then improve; 2) Organic matter content, nitrogen content, capillary moisture capacity, bulk density, and porosity all are remarkable correlation with other factors of soil physical-chemical properties, and they are the key factors of soil physical-chemical properties, which have important functions in advancing the soil nutrient cycle and improving the soil physical-chemical properties; 3 ) Principal component analysis also show that organic matter content, nitrogen content, potassium content, bulk density, moisture capacity, and porosity are the key factors in evaluating the degrees of rocky desertification. Based on these results, the theory, that is, bare rocks have a collected action for soil nutrients in karst rocky desertification ecosystem, was raised, and the response and its mechanism of soil physicalchemical properties to rocky desertification succession was presented. Results have important values in the protection of karst forest ecosystem and the control of rocky desertification.

Key Words : Karst; rocky desertification; soil physical-chemical properties; response; mechanism

石漠化是指在脆弱喀斯特生态环境下人类不合理的社会经济活动,造成人地矛盾突出、植被破坏、水土流失、岩石逐渐裸 露、土地生产力衰退甚至丧失, 地表呈现类似于荒漠化景观的演变过程或结果 ${ }^{[1-4]}$ 。我国西南喀斯特地区位于世界三大连片喀 斯特发育区之一的东亚片区中心, 面积约 54 万 $\mathrm{km}^{2}$ 。目前居住着 1 亿多人口、48 个少数民族 ${ }^{[2]}$, 贫困人口相对集中, 人地矛盾 非常突出, 坡地植被一旦破坏, 土壤侵蚀作用加剧, 导致稀薄土层全部流失, 造成严重的石漠化, 水分、养分调蓄能力迅速降 低 ${ }^{[5-6]}$ 。石漠化已经成为制约我国西南喀斯特地区区域经济社会发展的一个重大生态问题 ${ }^{[7-9]}$ 。

土壤是陆地生态系统的重要组成部分, 是生态系统诸多生态过程的载体, 是植物群落更新演替过程中不可或缺的研究内 容 ${ }^{[10]}$ 。通过对特定环境条件下生态系统演替过程中土壤理化性质变化的研究, 将有助于认识生态系统演变过程中地上与地下

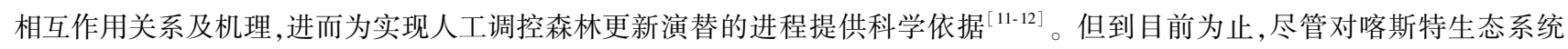
单一生态过程的研究较深人 ${ }^{[13]}$, 但对喀斯特生态系统土壤理化性质缺乏深人研究, 其时空分异及其对石漠化过程的响应尚无 研究 $^{[14]}$; 石漠化生态系统经过人工更新演替后, 土壤理化性质及变化趋势如何, 人工植被演替又怎样影响地下土壤的演变, 以 及构建怎样的森林植被才有利于该区域土壤性质的改善等问题, 尚缺乏研究。为此, 以中国西南典型喀斯特石漠化生态系统土 壤为研究对象, 研究不同等级石漠化环境土壤理化性质特征, 探讨石漠化过程中土壤理化性质变化的响应及其机制, 以期为中 国西南喀斯特森林生态保护和石漠化生态系统恢复重建提供理论支撑。

\section{1 研究区概况与方法}

\section{1 研究区概况}

研究选择了中国西南喀斯特地区 3 个典型石漠化区域作为研究区, 3 个研究区的地理位置和基本信息见表 1 和图 1 。

研究区 I 位于贵州省毕节市鸭池镇东南 $13 \mathrm{~km}$ 处,属长江流域乌江水系白浦河支流区。区内以喀斯特高原山地地貌类型 为主, 地势起伏大, 海拔为 1400-1742 $\mathrm{m}$ 。区内年均降雨量为 $863 \mathrm{~mm}$, 年最大降水量 $995 \mathrm{~mm}$, 年最小降水量 $618 \mathrm{~mm}$, 降雨量主 要分布在 7-9 月, 占全年总降雨的 52\%。岩石以碳酸盐类的石灰岩为主, 有部分侏罗纪紫色砂页岩、页岩分布。土壤以黄壤土 及紫砂土为主, 在洼地和平地有水源的地方有零星水稻土分布, 坡耕地以黄色石灰土属的岩泥土, 灌草丛为黑灰色石灰土。植 被为亚热带常绿落叶针阔混交林, 原生植被基本上被破坏, 现以次生植被为主。野生植被有以窄叶火棘 (Pyracantha angustifolia)、刺梨 (Rosa roxbunghii)、救军粮(Pyracantha fortuneana)、铁线莲 (Clematis florida) 等为主的藤、刺、灌丛, 以及零星分 布的青冈 (Cyclobalanopsis glauca)、马尾松 (Pinus massoniana)、光皮桦 (Betula luminifera) 为主的乔木林。

研究区 II 位于贵州省清镇市红枫镇簸箩村王家寨组, 距清镇市 $12 \mathrm{~km}$, 属长江流域乌江水系麦翁河支流区。区内地貌类型 为典型的喀斯特高原盆地, 地势平缓, 海拔为 1271-1451 $\mathrm{m}$ 。区内年均降雨量为 $1215 \mathrm{~mm}$, 降雨量主要分布在 4-8 月, 占全年 总降雨的 75\%。区内岩石多属三叠系的白云岩、泥质白云岩及页岩。土壤以黄壤、黄色石灰土为主。植被以农田植被为主, 自 然植被在小区中所占比重较小, 其中柏木 (Cupressus funebris) 是其常见乔木物种, 灌木层多为典型石灰岩有刺灌丛, 以金佛山荚 蒾(Viburnum chinshanense)、救军粮、野蓄薇 (Rosa multiflora)、悬钩子(Rubus corchorifolius)、亮叶鼠李( Rhamnus hemsleyana) 等为 主, 草本层常见种类有白茅 (Imperata cylindrica)、五节芒 (Miscanthus floridulu)、芒 (Miscanthus sinensis)、荩草 (Arthraxon hispidus)、铁线莲等。

研究区 III 位于贵州省安顺市北盘江花江河段峡谷两岸, 地貌类型为典型的喀斯特高原峡谷, 地势起伏大, 海拔为 450 $1450 \mathrm{~m}$, 相对高差达 $1000 \mathrm{~m}$ 。区内年均降雨量为 $1100 \mathrm{~mm}$, 降雨量主要分布在 5-10月,占全年总降雨的 $83 \%$ 。区内岩石多属 
三叠系的白云岩、泥质白云岩及页岩。土壤以黄壤、黄色石灰土为主。植被为亚热带常绿落叶针阔混交林,原生植被基本上被 破坏, 现以次生植被为主。野生植被是以窄叶火棘、刺梨、救军粮、铁线莲等为主的藤、刺、灌丛,以及零星分布的青冈、马尾松、 光皮桦为主的乔木林。

表 1 研究区基础信息及样方设置

Table 1 Basic information of experiment sites and sample plots set in the study

\begin{tabular}{|c|c|c|c|c|c|c|c|c|}
\hline $\begin{array}{l}\text { 研究区 } \\
\text { Experiment } \\
\text { sites }\end{array}$ & $\begin{array}{c}\text { 位置 } \\
\text { Location }\end{array}$ & $\begin{array}{l}\text { 中心点坐标 } \\
\text { Latitude and } \\
\text { longitude of } \\
\text { centre }\end{array}$ & $\begin{array}{c}\text { 海拔 } \\
\text { Altitude/m }\end{array}$ & $\begin{array}{c}\text { 地貌 } \\
\text { Landform }\end{array}$ & $\begin{array}{l}\text { 土壤类型 } \\
\text { Soil type }\end{array}$ & $\begin{array}{c}\text { 石漠化等级 } \\
\text { Degree of rocky } \\
\text { desertification }\end{array}$ & $\begin{array}{c}\text { 岩石裸露率 } \\
\text { Percentage } \\
\text { of exposed } \\
\text { rock } / \%\end{array}$ & $\begin{array}{c}\text { 样方数及编号 (括号内) } \\
\text { Sum and } \\
\text { serial number } \\
\text { of plots }\end{array}$ \\
\hline \multirow[t]{5}{*}{ I } & \multirow{5}{*}{$\begin{array}{c}\text { 贵州毕节 } \\
\text { 市鸭池 }\end{array}$} & $27^{\circ} 15.08^{\prime} \mathrm{N}$ & \multirow[t]{5}{*}{$1400-1742$} & 喀斯特 & 黄壤、黄色 & 强度 & $30-35$ & $3($ I $1-3)$ \\
\hline & & $105^{\circ} 21.263^{\prime} \mathrm{E}$ & & \multirow[t]{4}{*}{ 高原山地 } & \multirow[t]{4}{*}{ 石灰土 } & 中度 & $20-29$ & $3(\mathrm{I} 4-6)$ \\
\hline & & & & & & 轻度 & $0-5$ & $3($ I 7-9) \\
\hline & & & & & & 潜在 & $0-5$ & $3(\mathrm{I} 10-12)$ \\
\hline & & & & & & 无 & 0 & $3($ I 13-15) \\
\hline \multirow[t]{5}{*}{ II } & \multirow{5}{*}{$\begin{array}{c}\text { 贵州清镇市 } \\
\text { 红枫湖 }\end{array}$} & $26^{\circ} 30.961^{\prime} \mathrm{N}$ & \multirow[t]{5}{*}{$1271-1451$} & 喀斯特 & \multirow{5}{*}{$\begin{array}{c}\text { 黄壤、黄色 } \\
\text { 石灰土 }\end{array}$} & 强度 & $30-35$ & $3($ II 1-3) \\
\hline & & $106^{\circ} 20.328^{\prime} \mathrm{E}$ & & 高原盆地 & & 中度 & $20-29$ & $3($ II $4-6)$ \\
\hline & & & & & & 轻度 & $0-5$ & $3($ II 7-9) \\
\hline & & & & & & 潜在 & $0-5$ & $3($ II $10-12)$ \\
\hline & & & & & & 无 & 0 & $3($ II 13-15) \\
\hline \multirow[t]{5}{*}{ III } & \multirow{5}{*}{$\begin{array}{c}\text { 贵州安顺市 } \\
\text { 花江 }\end{array}$} & $25^{\circ} 39.40^{\prime} \mathrm{N}$ & \multirow[t]{5}{*}{$450-1450$} & 喀斯特 & \multirow{5}{*}{$\begin{array}{c}\text { 黄壤、黄色 } \\
\text { 石灰土 }\end{array}$} & 强度 & $30-35$ & $3($ III $1-3)$ \\
\hline & & $105^{\circ} 39.042^{\prime} \mathrm{E}$ & & 高原峡谷 & & 中度 & $20-29$ & $3($ III $4-6)$ \\
\hline & & & & & & 轻度 & $0-5$ & $3($ III $7-9)$ \\
\hline & & & & & & 潜在 & $0-5$ & $3($ III $10-12)$ \\
\hline & & & & & & 无 & 0 & $3($ III $13-15)$ \\
\hline
\end{tabular}

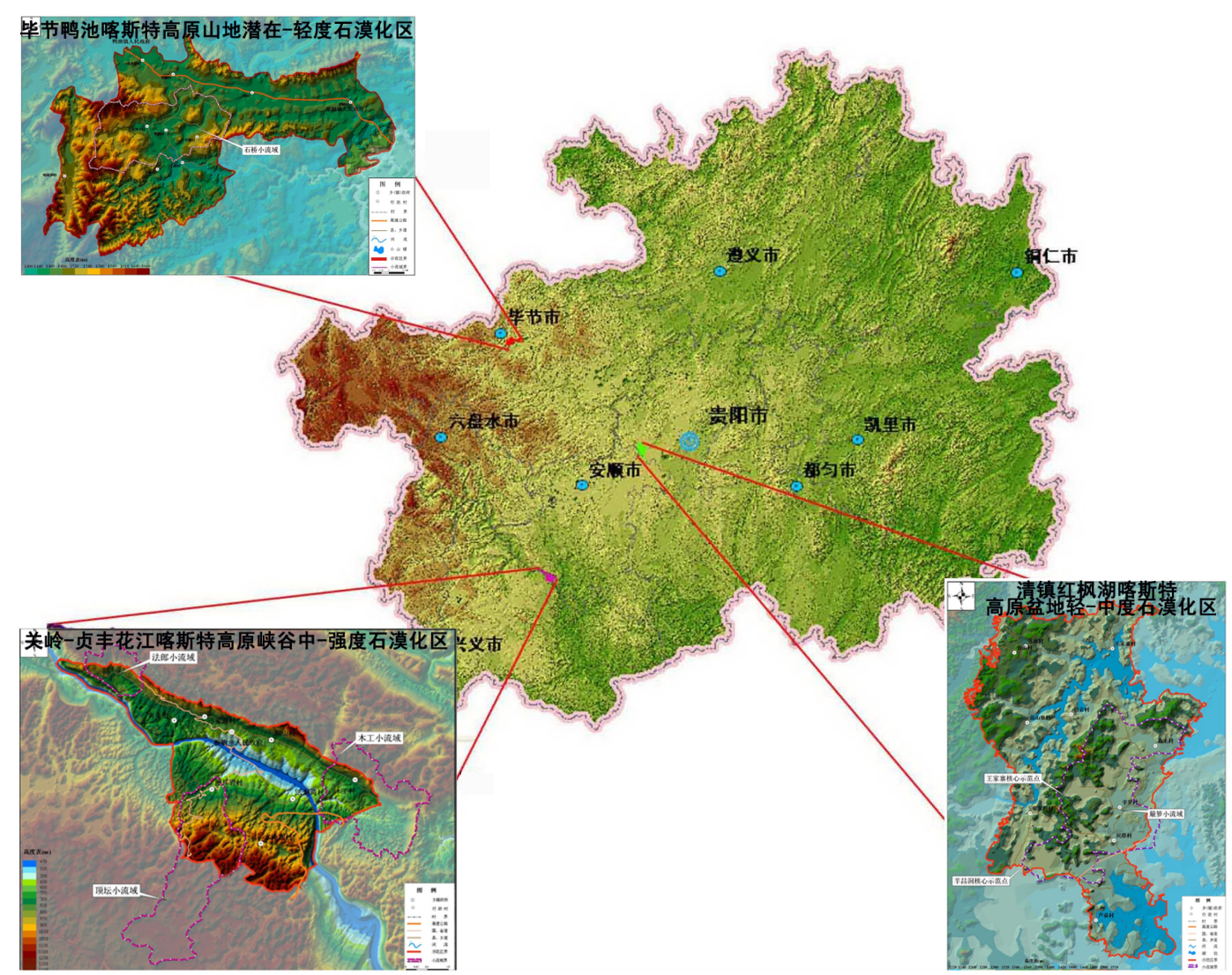

图 1 研究区位置及其概况

Fig.1 Location and basic information of experiment sites in this study 
1.2 研究方法

1.2.1 土壤样品采集

在对研究区详细踏查的基础上, 选取石漠化演替过程中 5 个典型阶段为研究对象,分别为无石漠化的原生森林、潜在石漠 化的疏林地、轻度石漠化的灌草地、中度石漠化的疏草地和强度石漠化的石旮昌地, 石漠化等级划分参照熊康宁等 ${ }^{[15]}$ 的方法。 在 3 个研究区分别针对每个研究对象设立面积为 $20 \mathrm{~m} \times 20 \mathrm{~m}$ 重复样地 3 个,共建立了 45 个土壤取样样地(表 1 )。所有的样 地除石漠化演替阶段不同外,其它的因子都大致一致,土壤是同质的,均为黄色石灰土。在样地中心按蛇形方式选 3 个采样点， 各点间距在 $5 \mathrm{~m}$ 之内。 2012 年 8 月和 2013 年 1 月分别在各样点用环刀 $(0-15 \mathrm{~cm})$ 取样 3 次重复,均匀混合组成待测土样。石 漠化区域土壤很薄, 部分仅有 $15 \mathrm{~cm}$ 左右, 因此以 $0-15 \mathrm{~cm}$ 土壤层中作为研究对象。

\subsection{2 土壤物理性质测定}

容重、田间持水量、自然含水量和毛管持水量测定采用环刀法; 总孔隙度用 $p_{\mathrm{t}}=93.947-32.995 \times b$ 来计算, $b$ 为容重, $p_{\mathrm{t}}$ 为总 孔隙度; 毛管孔隙度测定采用环刀法; 非毛管孔隙度用 $p_{\mathrm{o}}=p_{\mathrm{t}}-p_{\mathrm{c}}$ 来计算, $p_{\mathrm{o}}$ 为非毛管孔隙度, $p_{\mathrm{c}}$ 为毛管孔隙度; 渗透特性测定采 用双环渗透法。以上分析方法见森林土壤分析方法 ${ }^{[16]}$ 。

\subsection{3 土壤化学性质测定}

$\mathrm{pH}$ 值采用 2.5:1 的水土比,用电位计法测定; 有机质采用硫酸重铬酸钾氧化为容量法测定; 全氮采用硫酸钾为硫酸铜为硒 粉消煮,定氮仪自动分析法测定; 水解氮采用碱解扩散法测定; 全磷采用硫酸为高氯酸消煮为钼锑抗比色法测定; 有效磷采用碳 酸氢钠浸提为钼锑抗比色法测定; 全钾采用氢氟酸为高氯酸消煮火焰光度计法测定; 速效钾采用中性乙酸铵提取为火焰光度计 法测定; 土壤呼吸采用气室法进行测定。以上分析方法见土壤农业化学分析方法 ${ }^{[17]}$ 。

\subsection{4 数据处理与分析}

采用 Excel 软件进行绘图,利用 SPSS 16.0 软件进行方差分析、 $t$ 检验、多重比较 (Duncan 检验)、相关性分析和主成分分析 等统计分析 ${ }^{[18]}$ 。

\section{2 结果分析}

2.1 不同等级石漠化环境土壤理化性质

2.1.1 土壤物理性质

\section{(1) 土壤容重}

土壤容重是土壤紧实度的敏感性指标, 表征土壤的疏松程度与通气性, 是土壤质量的一个重要参数,其值大小与土壤的通 气性、透水性和根系生长阻力有关 ${ }^{[19]}$ 。研究显示, 不同等级石漠化环境土壤容重存在显著差异 (表 2)。潜在石漠化显著大于 中度和强度石漠化, 无石漠化、潜在和轻度石漠化土壤容重没有明显差异; 随着石漠化程度增加, 土壤容重有降低趋势。

(2) 土壤孔隙度

土壤孔隙状况直接影响着土壤的通气透水性及根系穿插的难易程度,对土壤中水、肥、气、热以及生物活性等发挥着不同的 作用 ${ }^{[20]}$ 。从表 2 看出, 不同等级石漠化土壤孔隙度差异显著, 潜在石漠化的土壤总孔隙度显著小于中度石漠化, 潜在石漠化的 毛管孔隙度显著小于强度石漠化,而非毛管孔隙度在不同等级石漠化环境无明显差异。

(3) 土壤自然含水量及持水状况

研究发现,不同等级石漠化环境土壤自然含水量无明显差异 (表 2)。土壤田间持水量和毛管持水量存在显著差异: 潜在石 漠化的土壤田间持水量显著小于强度石漠化, 对于毛管持水量, 潜在和轻度石漠化显著小于强度石漠化。可见,随着石漠化程 度增加, 土壤田间持水量和毛管持水量显著增加。

(4) 土壤渗透性

土壤渗透性是土壤理水调洪功能极为重要的特征参数之一, 是将地表径流转化为壤中流、地下径流的能力, 对土壤水土保 持及水源涵养功能影响极大 ${ }^{[21]}$ 。对于土壤渗透速率, 5 种不同等级石漠化环境土壤, 不管是上层饱和渗透率还是下层饱和渗 透率均无明显差异。

2.1.2 土壤化学性质

(1) 土壤有机质、 $\mathrm{pH}$ 值及土壤呼吸

土壤有机质是土壤固相部分的重要组分, 它与土壤矿物质共同作为林木营养的来源, 直接影响和改变土壤的一系列物理、 化学和生物学性质 ${ }^{[20]}$ 。研究表明(表 3), 潜在石漠化环境土壤有机质明显小于无石漠化,而无石漠化与轻度、中度和强度石漠 化土壤有机质无明显差异。土壤 $\mathrm{pH}$ 值研究显示, 无石漠化环境土壤 $\mathrm{pH}$ 值明显小于潜在、轻度、中度和轻度石漠化,但无石漠 化和强度石漠化环境土壤为酸性, $\mathrm{pH}$ 值均小于 7, 而其它土壤 $\mathrm{pH}$ 值均大于 7 。对于土壤呼吸, 不同等级石漠化环境间无显著 差异。 


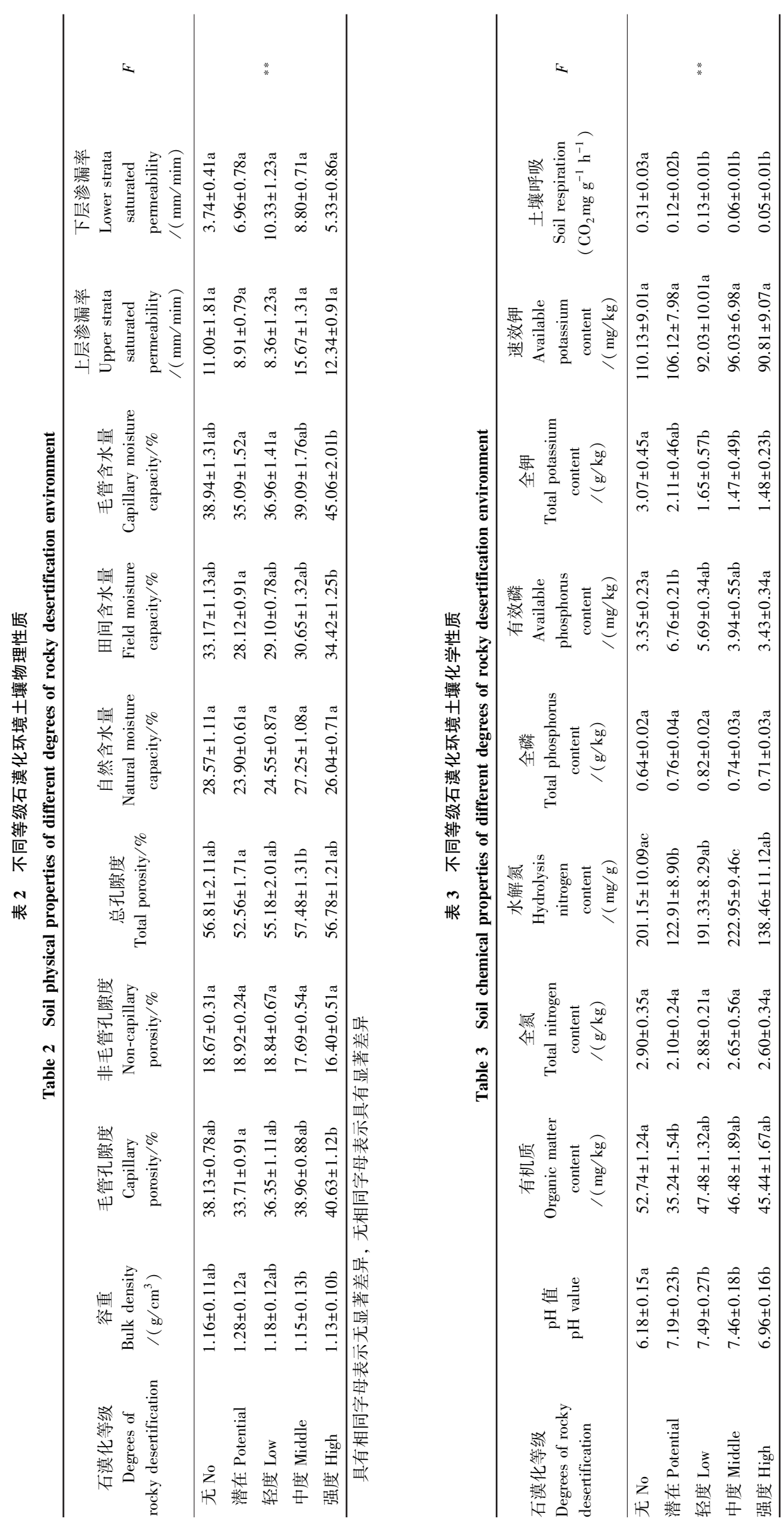


(2) 土壤氮素

全氮是土壤氮素养分的储备指标, 在一定程度上说明土壤氮的供应能力 ${ }^{[22]}$; 水解氮能较好地反映出近期内土壤氮的供应 状况和氮的释放速率。研究表明,不同等级石漠化环境土壤全氮无明显差异,显示了石漠化环境土壤受母岩影响明显。而不同 等级石漠化环境土壤水解氮存在明显差异,无石漠化和中度石漠化显著大于潜在石漠化,强度石漠化显著小于中度石漠化,显 示土壤水解氮的变化与石漠化演化无明显相关,这可能与水解氮聚集效果强烈、取样随机有关。

(3) 土壤磷素

全磷是衡量土壤中各种形态磷总和的一个指标,其值大小受土壤母质、成土作用影响很大,另外与土壤质地和有机质有关 系 ${ }^{[23]}$ 。研究显示, 不同等级石漠化环境土壤全磷无显著差异。而土壤有效磷在不同等级石漠化环境存在显著变化, 潜在石漠 化显著大于无石漠化和强度石漠化, 随石漠化程度增加,显示了先增加后降低的趋势。

(4) 土壤钾素

土壤钾是植物光合作用、淀粉合成和糖类转化所必需的元素, 也是衡量土壤肥力的一个重要指标 ${ }^{[23]}$; 速效钾是植物能利用 的钾, 占土壤中钾素的极少部分, 能真实反映土壤中钾素的供应情况。研究结果显示, 不同等级石漠化环境土壤全钾存在显著 差异, 无石漠化显著大于轻度、中度和强度石漠化,而土壤有效钾在不同等级石漠化环境无明显变化。

2.2 石漠化环境土壤理化性质相关性

不同等级石漠化环境土壤理化性质相关性分析表明 (表 4), 土壤有化学性质的机质和氮素与土壤其它绝大多数理化因子 具有明显的相关性。有机质与全氮、水解氮、速效钾、总孔隙度、自然含水量、毛管持水量、田间持水量、上层渗透率成极显著正 相关, 与全磷、下层渗透率成显著正相关,与土壤容重成极显著负相关。全氮与 $\mathrm{pH}$ 值、有机质、全磷、水解氮、速效钾、总孔隙 度、毛管持水量、田间持水量和上层渗透率成极显著正相关, 与容重成极显著负相关, 与有效磷成显著正相关。水解氮与有机 质、全氮、全磷、孔隙度、毛管持水量、田间持水量和上层渗透率成极显著正相关，与 $\mathrm{pH}$ 值、速效钾、下层渗透率成显著正相关， 与容重成极显著负相关。相关性分析也显示, 土壤物理性质的毛管持水量、容重和孔隙度与其它绝大多数理化因子具有明显的 相关性。由此可见, 石漠化环境有机质、氮素、毛管持水量、容重和孔隙度是土壤理化性质的关键因子, 在改善土壤理化性质和 促进养分循环方面起着关键作用。

2.3 石漠化环境土壤理化性质季节波动

对不同时间 (1 月和 8 月) 定点采样检测的土壤理化性质 $t$ 检验分析 (表 5) 显示, 18 个土壤理化性质指标有 7 个指标存在 (极) 显著差异,其余 11 个指标无明显变化。土壤物理性质的土壤容重、土壤总孔隙度和毛管持水量等 3 个指标在不同季节存 在显著差异,夏季 ( 8 月) 的土壤容重显著的小于冬季 (1月), 而夏季的土壤总孔隙度和毛管持水量显著的大于冬季; 毛管孔隙 度和土壤自然含水量在不同季节存在极显著的差异,夏季的毛管孔隙度极显著大于冬季,而夏季的土壤自然含水量极显著小于 冬季。土壤化学性质的全钾和有效磷在不同季节也显示了显著的差异,夏季的土壤全钾和有效磷均显著小于冬季。

2.4 基于土壤理化性质的石漠化主成分分析

基于土壤 18 个理化性质指标的石漠化主成分分析表明(表 6), 主成分 1 的贡献率为 $40.83 \%$,主成分 2 的贡献率为 $30.13 \%$, 主成分 3 的贡献率为 $25.25 \%$, 累计贡献率已达 $96.21 \%$ 。可见, 前 3 个主成分保留了 18 个土壤理化性质指因子评价石 漠化特征的绝大部分信息, 因此选取这 3 个主成分作为评价石漠化土壤演变的依据。主成分 1 中,有机质、全氮、水解氮、全钾、 速效钾、土壤容重、田间持水量、自然含水量的毛管含水量的权重系数较大,显示主成分 1 主要反映了土壤有机质、氮素、钾素、 容重和持水状况表征石漠化的信息。主成分 2 中,毛管孔隙度、非毛管孔隙度、总孔隙度、下层饱和渗透率、pH 值的权重系数较 大,显示主成分 2 主要反映了土壤 $\mathrm{pH}$ 值、孔隙度和渗透性表征石漠化的信息。主成分 3 中, 土壤呼吸、全磷和有效磷的权重系 数较大,显示主成分 3 主要反映了土壤呼吸和磷素表征石漠化的信息。

\section{3 讨论与结论}

3.1 石漠化演变过程中土壤理化性质的响应及其机制

研究显示,不同等级石漠化环境土壤全氮、全磷、有效钾等理化因子无明显差异,表明石漠化环境土壤受碳酸盐岩母岩影响 明显。土壤是在气候、植被、地形、母质等因子综合作用下形成的,并随着植被演替的进行总是在不断地发生变化 ${ }^{[24]}$ 。本研究 对中国西南喀斯特地区典型石漠化区域 5 个典型石漠化演替阶段的土壤理化性质研究显示, 石漠化环境土壤变化与植物群落 的演替具有明显的相关性。在一定程度上, 植物群落的正向演替是土壤养分不断积累、物理性能不断改善的过程, 而植物群落 的逆向演替是土壤不断退化的过程。

喀斯特脆弱生态系统的退化是以强烈的人类干扰为驱动力、以植被减少为诱因、以土地生产力退化为本质、以出现类似荒 漠化景观为标志的复合过程 ${ }^{[1]}$ 。长期以来, 人们一直认为随着石漠化程度增加, 土壤退化程度亦是随之增加, 强度石漠化环境 的土壤退化最严重 ${ }^{[1,25-26]}$ 。然而, 事实却并非如此, 研究结果显示, 喀斯特石漠化环境土壤不管是物理性质还是化学性质的演 变均不是随着石漠化等级的增加而一直退化, 而是一个先退化后改善的过程。究其原因,这应该与石漠化环境裸露岩石聚集效 应有关。这种聚集效应指的是裸露的岩石将大气沉降的养分及其岩溶产物汇聚到周围的土壤中 (图2)。随着石漠化程度增 


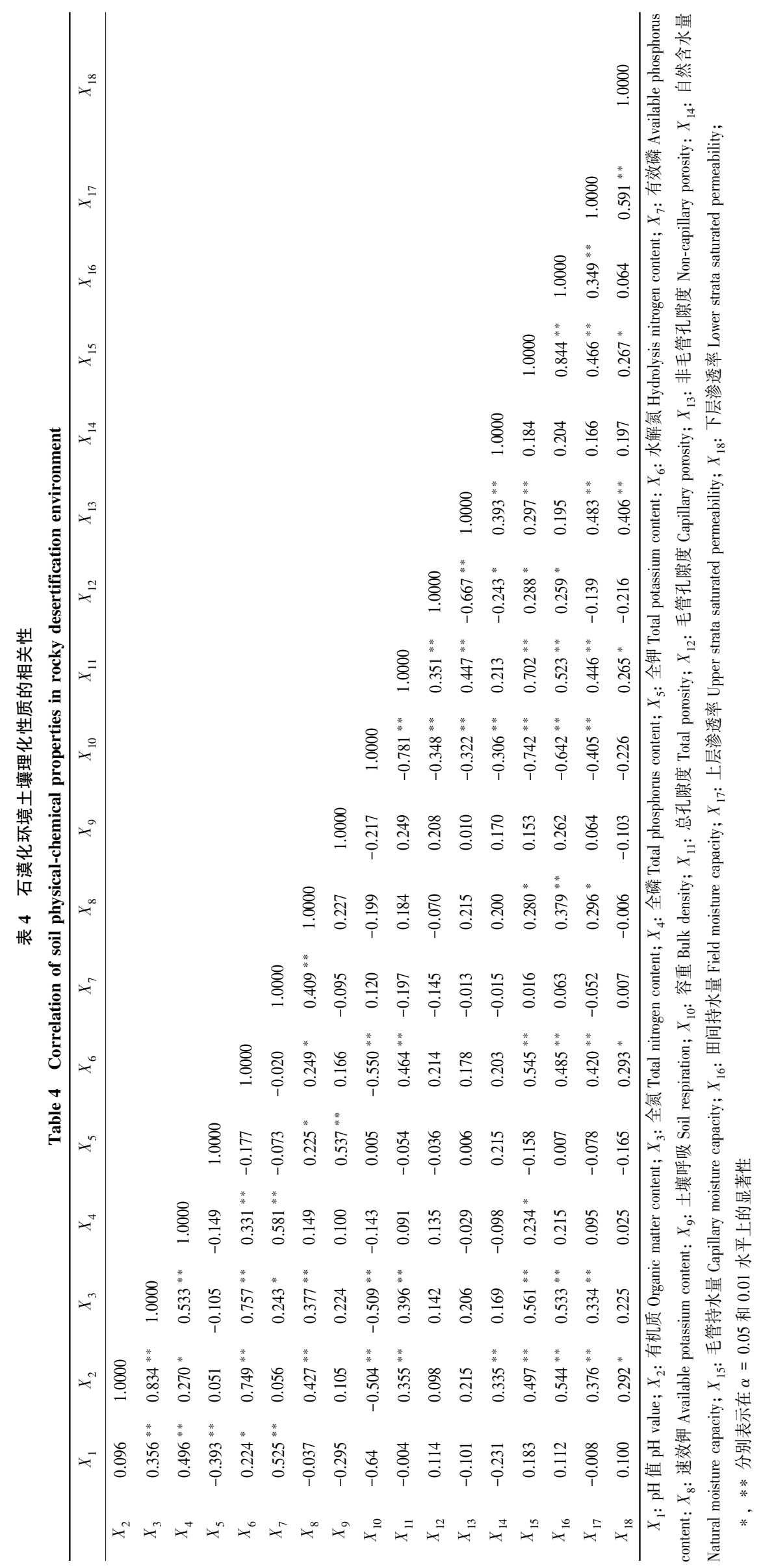


表 5 不同季节石漠化环境土壤理化性质变化

Table 5 Comparison of soil physical-chemical properties of rocky desertification environment between seasons of summer and winter

\begin{tabular}{|c|c|c|c|c|c|c|c|}
\hline \multirow{2}{*}{$\begin{array}{l}\text { 土壤理化性质 } \\
\text { Soil physical-chemical properties }\end{array}$} & \multicolumn{3}{|c|}{$\begin{array}{c}\text { 夏季 ( } 8 \text { 月) } \\
\text { Summer (August) }\end{array}$} & \multicolumn{3}{|c|}{$\begin{array}{c}\text { 冬季(1 月) } \\
\text { Winter (January) }\end{array}$} & \multirow[b]{2}{*}{$t$} \\
\hline & 样本值 $N$ & 平均值 Mean & $\begin{array}{c}\text { 标准误 } \\
\text { Std. Error } \\
\text { Mean }\end{array}$ & 样本值 $N$ & 平均值 Mean & $\begin{array}{l}\text { 标准误 } \\
\text { Std. Error } \\
\text { Mean }\end{array}$ & \\
\hline $\begin{array}{l}\text { 容重 } /\left(\mathrm{g} / \mathrm{cm}^{3}\right) \\
\text { Bulk density }\end{array}$ & 37 & 1.1578 & 0.0280 & 37 & 1.2421 & 0.0224 & $-2.355^{*}$ \\
\hline $\begin{array}{l}\text { 毛管孔隙度/\% } \\
\text { Capillary porosity }\end{array}$ & 38 & 39.704 & 1.2278 & 37 & 33.880 & 0.7200 & $4.092^{* * *}$ \\
\hline $\begin{array}{l}\text { 非毛管孔隙度/\% } \\
\text { Non-capillary porosity }\end{array}$ & 38 & 17.268 & 1.3780 & 37 & 19.519 & 0.8843 & -1.375 \\
\hline $\begin{array}{l}\text { 总孔隙度/\% } \\
\text { Total porosity }\end{array}$ & 38 & 57.235 & 0.9754 & 37 & 53.303 & 0.8205 & $3.085^{*}$ \\
\hline $\begin{array}{l}\text { 自然含水量/\% } \\
\text { Natural moisture capacity }\end{array}$ & 37 & 23.478 & 1.4077 & 37 & 28.479 & 1.2284 & $-2.676^{* *}$ \\
\hline $\begin{array}{l}\text { 田间含水量/\% } \\
\text { Field moisture capacity }\end{array}$ & 38 & 31.861 & 1.1287 & 37 & 29.365 & 1.0582 & 1.613 \\
\hline $\begin{array}{l}\text { 毛管含水量/\% } \\
\text { Capillary moisture capacity }\end{array}$ & 38 & 40.127 & 1.1949 & 37 & 35.951 & 1.4081 & $2.261^{*}$ \\
\hline $\begin{array}{l}\text { 上层渗透率 } /(\mathrm{mm} / \mathrm{mim}) \\
\text { Upper strata saturated permeability }\end{array}$ & 38 & 10.851 & 1.5728 & 38 & 10.750 & 1.3364 & 0.049 \\
\hline $\begin{array}{l}\text { 下层渗透率/ }(\mathrm{mm} / \mathrm{mim}) \\
\text { Lower strata saturated permeability }\end{array}$ & 38 & 6.8144 & 1.3948 & 38 & 6.7160 & 1.3026 & 0.052 \\
\hline $\begin{array}{l}\mathrm{pH} \text { 值 } \\
\mathrm{pH} \text { value }\end{array}$ & 39 & 6.9923 & 0.1527 & 39 & 6.9907 & 0.1579 & 0.007 \\
\hline $\begin{array}{l}\text { 有机质 } /(\mathrm{mg} / \mathrm{kg}) \\
\text { Organic matter content }\end{array}$ & 39 & 43.079 & 3.2504 & 39 & 46.212 & 3.1167 & -0.696 \\
\hline $\begin{array}{l}\text { 全氮/ }(\mathrm{g} / \mathrm{kg}) \\
\text { Total nitrogen content }\end{array}$ & 39 & 2.5223 & 0.2028 & 39 & 2.6310 & 0.2004 & -0.381 \\
\hline $\begin{array}{l}\text { 全磷/ }(\mathrm{g} / \mathrm{kg}) \\
\text { Total phosphorus content }\end{array}$ & 39 & 0.7354 & 0.0512 & 39 & 0.7182 & 0.0440 & 0.255 \\
\hline $\begin{array}{l}\text { 全钾 } /(\mathrm{g} / \mathrm{kg}) \\
\text { Total potassium content }\end{array}$ & 39 & 1.6982 & 0.1651 & 39 & 2.5084 & 0.2717 & $-2.549^{*}$ \\
\hline $\begin{array}{l}\text { 水解氮 } /(\mathrm{mg} / \mathrm{g}) \\
\text { Hydrolysis nitrogen content }\end{array}$ & 39 & 174.39 & 15.9940 & 39 & 167.33 & 13.6736 & 0.335 \\
\hline $\begin{array}{l}\text { 有效磷 } /(\mathrm{mg} / \mathrm{kg}) \\
\text { Available phosphorus content }\end{array}$ & 39 & 3.942 & 0.5162 & 39 & 5.7723 & 0.6947 & $-0.075^{*}$ \\
\hline $\begin{array}{l}\text { 速效钾 } /(\mathrm{mg} / \mathrm{kg}) \\
\text { Available potassium content }\end{array}$ & 39 & 95.407 & 3.7478 & 39 & 107.45 & 5.3436 & -1.845 \\
\hline
\end{tabular}

表 6 基于土壤理化性质的石漠化主成分分析

Table 6 Principal component analysis of rocky desertification based on plant diversity and soil physical-chemical properties

\begin{tabular}{lrrr}
\hline 土壤理化性质 & \multicolumn{3}{c}{ 主成分 Principal components } \\
\cline { 2 - 4 } Soil physical-chemical properties & \multicolumn{1}{c}{ - } & \multicolumn{1}{c}{3} \\
\hline 容重 Bulk density & -0.876 & 0.032 & -0.481 \\
毛管孔隙度 Capillary porosity & 0.003 & -0.919 & 0.386 \\
非毛管孔隙度 Non-capillary porosity & 0.000 & 0.988 & -0.130 \\
总孔隙度 Total porosity & 0.008 & 0.814 & 0.579 \\
田间持水量 Field moisture capacity & 0.834 & -0.329 & -0.401 \\
土壤自然含水量 Natural moisture capacity & 0.785 & 0.507 & -0.229 \\
毛管持水量 Capillary moisture capacity & 0.747 & -0.458 & 0.417 \\
上层渗透率 Upper strata saturated permeability & 0.403 & 0.442 & 0.776 \\
下层渗透率 Lower strata saturated permeability & -0.399 & 0.896 & 0.173 \\
pH & -0.083 & -0.813 & 0.555 \\
\hline
\end{tabular}




\begin{tabular}{|c|c|c|c|}
\hline \multirow{2}{*}{$\begin{array}{l}\text { 土壤理化性质 } \\
\text { Soil physical-chemical properties }\end{array}$} & \multicolumn{3}{|c|}{ 主成分 Principal components } \\
\hline & 1 & 2 & 3 \\
\hline 有机质 Organic matter content & 0.996 & 0.036 & -0.066 \\
\hline 全氮 Total nitrogen content & 0.974 & -0.032 & 0.152 \\
\hline 水解氮 Hydrolysis nitrogen content & 0.814 & 0.188 & 0.450 \\
\hline 有效磷 Available phosphorus content & 0.506 & 0.088 & -0.855 \\
\hline 全磷 Total phosphorus content & -0.028 & 0.632 & 0.661 \\
\hline 全钾 Total potassium content & 0.911 & -0.160 & -0.381 \\
\hline 速效钾 Available potassium content & 0.802 & 0.446 & -0.349 \\
\hline 土壤呼吸 Soil respiration & -0.228 & 0.185 & -0.907 \\
\hline 特征值 Eigenvalue & 7.349 & 5.422 & 4.546 \\
\hline 贡献率 Percent/\% & 40.829 & 30.125 & 25.253 \\
\hline 累积贡献率 Cumulative percent $/ \%$ & 40.829 & 70.953 & 96.206 \\
\hline
\end{tabular}

加, 裸岩聚集效应逐渐增强。在强度石漠化环境中, 这种聚集效 应非常明显,加之水土流失作用减弱,致使退化的土壤养分和物 理性能得到改善。本研究结果也显示, 石漠化环境土壤演变过 程中,有机质、氮素、容重和持水状况等是其关键因子, 在改善土 壤理化性质和促进养分循环方面起着关键作用。

综上所述,石漠化演变过程中土壤理化性质的响应及其机 制可归纳为:无石漠化环境由于森林植被毁坏,土壤养分随着水 土流失作用而流失,加之植被调落物有机质输人减少, 导致土壤 退化。随着石漠化等级不断增加, 裸露岩石聚集效应逐渐明显, 汇集大气沉降养分和岩溶产物,增加了土壤氮素和有机物的输 人; 同时随着石漠化程度增加, 因可流失的土壤越来越少, 导致 水土流失越来越弱, 土壤养分流失微弱, 在强烈裸露岩石聚集效 应和微弱的水土流失作用下, 强度石漠化环境土壤养分和物理 性能得到了明显的改善(图 3)。

\section{2 石漠化环境土壤理化性与石漠化退化生态系统恢复重建}

长期以来, 人们一直认为喀斯特石漠化生态系统土壤退化 随石漠化程度增加而增强, 强度石漠化环境土壤退化最严 重 ${ }^{[2,25-26]}$ 。而本研究显示, 喀斯特石漠化生态系统土壤理化性 质演变并非如此, 而是随着石漠化程度增加先退化后改善的一 个过程。强度石漠化和无石漠化土壤条件明显好于其他等级石 漠化环境,潜在和轻度石漠化环境土壤条件反而是最差的。这 一研究结果很好解释了为什么喀斯特地区裸岩石山植被能够演 替成顶级森林群落并能够维系稳定。

同时,这一研究结果在指导喀斯特石漠化生态系统恢复重 建中具有极其重要意义。石漠化已经是制约我国西南喀斯特地 区区域经济发展和地方社会稳定的重大生态问题,严重阻碍了 我国同步小康战略目标的实现 ${ }^{[5,14,27]}$ 。自 2008 年以来,石漠化 治理已经成为我国社会经济发展建设中一项重要内容, 投人了 大量的人力物力开展石漠化治理 ${ }^{[2,5]}$ 。然而, 治理效果并不理 想。其中一个重要原因就是石漠化治理缺乏对石漠化环境土壤 的深人研究 ${ }^{[26,28-29]}$, 导致相关技术措施仍停留在经验总结层面、 难说科学,甚至是错误。例如,在石漠化治理领域,长期以来,人 们一直认为 (极)强度石漠化环境,植被恢复措施只能是封山育 林, 人工种植措施是不可能成功的,甚至是在一些地方石漠化治 理规程中也是这样总结的 ${ }^{[2]}$ 。然而, 本研究结果不能支持这一观点, (极) 强度石漠化环境土壤条件不但不比潜在-轻度石漠化

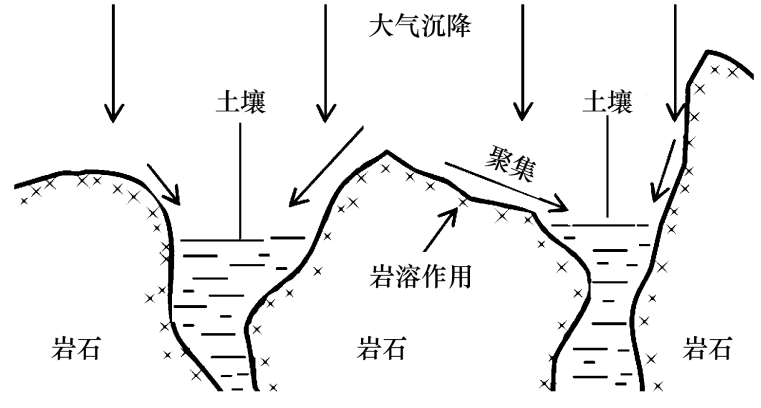

图 2 石漠化环境裸露岩石对土壤养分的聚集作用示意图

Fig.2 The action of soil nutrients collected by exposed rocks in rocky desertification ecosystem

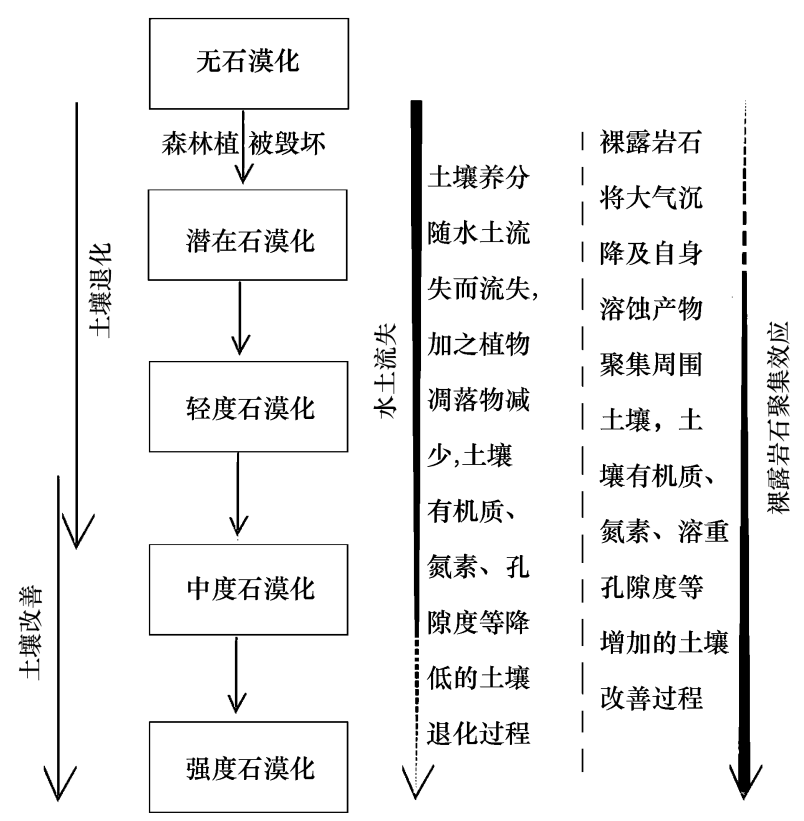

图 3 石漠化演变过程中土壤理化性质的响应及其机制

Fig.3 Response and its mechanism of soil physical-chemical properties to rocky desertification succession 
环境差,而且优于潜在-轻度石漠化环境土壤,完全应该实施人工造林措施修复石漠化。这一结论已被一些地区石漠化治理实 践所证实,在贵州花江石漠化治理示范区的(极)强度石漠化环境土壤上种植任豆树 (Zenia insignis, 一种高大乔木) 非常成功。 相反潜在-轻度石漠化环境土壤很贫痊、土层薄, 采取人工种植恢复植被措施往往不能成功,这一论断同样被众多已实施的石漠 化实践所证实。

石漠化治理是一项复杂的综合工程,需要林业、农业、水利等多领域的合作 ${ }^{[2,27,30]}$ 。然而, 长期以来由于石漠化治理技术 措施缺乏对土壤深人的理论研究支撑,基本上是经验式的总结提炼, 导致不同地区、不同领域、不同专家总结了纷繁复杂的治理 技术和模式 ${ }^{[2,30-31]}$, 在这些技术和模式中存在大量的混乱,甚至是出现了完全矛盾的观点。例如,部分专家对(极)强度石漠化 环境种植皇竹草 (Pennisetum hydridum)、金银花 (Lonicera Japonica) 等大水大肥物种一直持否定态度,认为 (极) 强度石漠化环境 土壤不可能支撑这些物种的生长。这些物种在(极)强度石漠化环境土壤生长的非常好,这一现象也支持了研究结果。对中国 西南喀斯特森林生态保护和石漠化生态系统恢复重建具有一定的理论意义和实践指导价值。

\section{References:}

[ 1 ] LeGrand H E. Hydrological and ecological problems of karst regions: Hydrological actions on limestone regions cause distinctive ecological problems. Science, 1973, 179(4076): 859-864.

[ 2 ] Xiong K N, Chen Y B, Chen H. Dian Shi Cheng Jin-Control Techniques and Pattern of Guizhou Stony Desertification. Guiyang: Guizhou Science and Technology Press, 2011: 125-139.

[ 3 ] Zheng D. Research of China Ecologic and Geographical District System. Beijing: Commercial Press China, 2008 : $327-339$.

[ 4 ] Zhang X B, Wang S J, Cao J H, Wang K L, Meng T Y, Bai X Y. Characteristics of water loss and soil erosion and some scientific problems on karst rocky desertification in southwest China karst area. Carsologica Sinica, 2010, 29(3) : 274-279.

[ 5 ] Xu E Q, Zhang H Q, Li M X. Mining spatial information to investigate the evolution of karst rocky desertification and its human driving forces in Changshun, China. Science of the Total Environment, 2013, 458-460: 419-426.

[ 6 ] Wang S J, Ji H B, Ouyang Z Y, Zhou D Q, Zheng L P, Li T Y. Preliminary study of the process of carbonate rock weathered into soil. Science in China (Series D), 1999, 29(5): 441-449.

[ 7 ] Wang S J, Zhang D F, Li R L. Mechanism of rocky desertification in the karst mountain areas of Guizhou province, southwest China. International Review for Environmental Strategies, 2002, 3(1): 123-135.

[ 8 ] Sweeting M M. Karst in China: Its Geomorphology and Environment. Berlin: Springer-Verlag, 1995: $112-118$.

[ 9 ] Li Y B, Shao J G, Bai X Y. The relations between land use and karst rocky desertification in a typical karst area, China. Environmental Geology, $2009,57(3): 621-627$.

[10] Cai Y L. Preliminary research on ecological reconstruction in karst mountain poverty areas of southwest China. Advances in Earth Science, 1996,11 (6) : 602-606.

[11] Wei Q, Ling L, Chai C S, Zhang G Z, Yan P B, Tao J X, Xue R. Soil physical and Chemical properties in forest succession process in Xinglong Mountain of Gansu. Acta Ecologica Sinica, 2012, 32(15) : 4700-4713.

[12] Kobza R M, Trexler J C, Loftus W F. Community structure of fishes inhabiting aquatic refuges in a threatened karst wetland and its implications for ecosystem management. Biological Conservation, 2004, 116(2): 153- 165.

[13] Zhang X B, Bai X Y, He X B. Soil creeping in the weathering crust of carbonate rocks and underground soil losses in the karst mountain areas of southwest China. Carbonates and Evaporites, 2011, 26(2) : 149-153.

[14] Liu C Q, Liang Y C, Li S L, Piao H C, Tu C L, Liu T Z, Zhang W, Zhu S F. Researches on biogeochemical processes and nutrient cycling in karstic ecological systems, southwest China: A review. Earth Science Frontiers, 2009, 16(6) : 1-12.

[15] Xiong K N, Li P, Zhou Z F. Remote Sensing of Karst Stony Desertification-A Typical Research of GIS/Taking Guizhou Province as An Example. Beijing: Geology Publishing House, 2002: 134-137.

[16] Ma X H. Methodological Guidelines for Forest Ecosystem Location Research. Beijing: Chinese Science and Technology Press, 1994 : $25-135$.

[17] Lu R K. Analytical Methods of Soil and Agricultural Chemistry. Beijing: China Agricultural Science and Technology Press, 2000 : $18-96$.

[18] Du R Q. Biostatistics. 3rd ed. Beijing: Higher Education Press, 2009: 25-28, 123-145.

[19] Zheng Y S, Chen L G, Hong W. Study on productivity and soil properties of mixed forests of Chinese fir and phyllostachys heterocycla cv. pubescens. Scientia Silvae Sinicae, 1998, 34( S1) : 16-25.

[20] Liu H Y, Huang J G. Dynamics of soil properties under secondary succession forest communities in Mt. Jinyu. Chinese Journal of Applied Ecology, $2005,16(11): 2041-2046$.

[21] Wu Q X, Han B, Li Y Y. Characteristics of soil infiltration in watersheds in Loess Hilly Region. Science of Soil and Water Conservation, 2004, 2 (2) : $1-5$.

[22] Lin D X, Fan H B, Su B Q, Liu C L, Jiang Z K, Shen B G. Effect of interplantation of broad leaved trees in pinus massoniana forest on physical and chemical properties of the soil. Acta Pedologica Sinica, 2004, 41(4) : 655-659.

http ://www.ecologica.cn 
[23] Ding S L, Yang N G, Zhao C C, Yang Q M, Wang S, Dong X. Soil physical and chemical properties in water conservation forest in eastern Qinghai Province. Bulletin of Soil and Water Conservation, 2010, 30(6): 1-6.

[24] Kang B, Liu S R, Cai D X, Lu L H, He R M, Gao Y X, Di W Z. Soil physical and chemical characteristics under different vegetation restoration patterns in China south subtropical area. Chinese Journal of Applied Ecology, 2010, 21( 10) : 2479-2486.

[25] Luo G J, Li Y B, Wang S J, Cheng A Y, Dan W L. Comparison of ecological significance of landscape diversity changes in karst mountains: a case study of 4 typical karst area in Guizhou Province. Acta Ecologica Sinica, 2011, 31(14) : 3883-3889.

[26] Liu F, Wang S J, Liu Y S, He T B, Luo H B, Long J. Changes of soil quality in the process of karst rocky desertification and evaluation of impact on ecological environment. Acta Ecologica Sinica, 2005, 25(3) : 639-644.

[27] Peng S L, Lu H F. Some key points of restoration ecology. Acta Ecologica Sinica, 2003, 23( 7) : 1249-1257.

[28] Zhu S Q. Research of Karst Forest Ecology ( III ). Guiyang: Guizhou Science and Technology Press, 2003 : $172-179$.

[29] Yao C H, Jiang Z C, Yuan D X. Vegetation karst effects on the karst area of Southwest China. Acta Geoscientia Sinica, 2001, 22(2) : 159-164.

[30] Su W C. Controlling model for rocky desertification of karst mountainous region and its preventing strategy in Southwest, China. Journal of Soil and Water Conservation, 2002, 16(2): 29-32, 79-79.

[31] Du Y X, Pan G X, Li L Q, Hu Z L, Wang X Z. Leaf N/P ratio and nutrient reuse between dominant species and stands: predicting phosphorus deficiencies in karst ecosystems, southwestern China. Environmental Earth Sciences, 2011, 64(2) : 299-309.

\section{参考文献：}

[ 2 ] 熊康宁, 陈永毕, 陈吘. 点石成金一一贵州石漠化治理技术与模式. 贵阳: 贵州科技出版社, 2011: 125-139.

[ 3 ] 郑度. 中国生态地理区域系统研究. 北京: 商务印书馆, 2008: 327-339.

[ 4] 张信宝, 王世杰, 曹建华, 王克林, 孟天友, 白晓永. 西南喀斯特山地水土流失特点及有关石漠化的几个科学问题. 中国岩溶, 2010, 29 (3) : 274-279

[ 6 ] 王世杰, 季宏兵, 欧阳自远, 周德全, 郑乐平, 黎廷宇. 碳酸盐岩风化成土作用的初步研究. 中国科学(D 辑)，1999，29(5)：441-449.

[10］蔡运龙. 中国西南岩溶石山贫困地区的生态重建. 地球科学进展, 1996, 11(6)：602-606.

[11］魏强, 凌雷, 柴春山, 张广忠, 间沛斌, 陶继新, 薛点. 甘肃兴隆山森林演替过程中的土壤理化性质. 生态学报, 2012, 32(15)： 4700-4713.

[14] 刘丛强, 郎羿超, 李思亮, 朴何春, 涂成龙, 刘涛泽, 张伟, 朱书法. 喀斯特生态系统生物地球化学过程与物质循环研究: 重要性、现状 与趋势. 地学前沿, 2009, 16(6): 1-12.

[15］熊康宁, 黎平, 周忠发. 喀斯特石漠化的遥感-GIS 典型研究- 以贵州省为例. 北京: 地质出版社, 2002: 134- 137.

[16] 马雪华. 森林生态系统定位研究方法. 北京: 中国科学技术出版社, 1994: 25-135.

[17］鲁如坤. 土壤农业化学分析方法. 北京: 中国农业科技出版社, 2000: 18-96.

[18］杜荣寒. 生物统计学 (第三版). 北京: 高等教育出版社, 2009: 25-28, 123-145.

[19] 郑郁善, 陈礼光, 洪伟. 毛竹杉木混交林生产力和土壤性状研究. 林业科学, 1998, 34( S1 ) : 16-25.

［20］刘鸿雁，黄建国. 缙云山森林群落次生演替中土壤理化性质的动态变化. 应用生态学报, 2005，16(11) : 2041-2046.

[21] 吴钦孝, 韩冰, 李秧秧. 黄土丘陵区小流域土壤水分人渗特征研究. 中国水土保持科学, 2004, 2(2): 1-5.

[22] 林德喜, 㚞后保, 苏兵强, 刘春华, 蒋宗垲, 沈宝贵. 马尾松林下套种阔叶树土壤理化性质的研究. 土壤学报, 2004, 41(4)：655-659.

[23] 丁绍兰, 杨宁贵, 赵串串, 杨乔媚, 王湜, 董旭. 青海省东部黄土丘陵区主要林型土壤理化性质. 水土保持通报, 2010, 30(6): 1-6.

[24] 康冰, 刘世荣, 蔡道雄, 卢立华, 何日明, 高妍夏, 迪玮峙. 南亚热带不同植被恢复模式下土壤理化性质. 应用生态学报, 2010, 21(10): 2479-2486

[25] 罗光杰, 李阳兵, 王世杰, 程安云, 丹文丽. 岩溶山区景观多样性变化的生态学意义对比一一贵州四个典型地区为例. 生态学报, $2011,31(14)$ : 3883-3889

[26] 刘方, 王世杰, 刘元生, 何腾兵, 罗海波, 龙健. 喀斯特石漠化过程土壤质量变化及生态环境影响评价. 生态学报, 2005, 25(3)： 639-644.

[27］彭少麟, 陆宏芳. 恢复生态学焦点问题. 生态学报, 2003, 23(7) : 1249-1257.

[28］朱守谦. 喀斯特森林生态研究 (III). 贵阳: 贵州科技出版社, 2003：172-179.

[29] 姚长宏, 蒋忠诚, 袁道先. 西南岩溶地区植被喀斯特效应. 地球学报, 2001，22(2)：159-164.

[30］苏维词. 中国西南岩溶山区石漠化的现状成因及治理的优化模式. 水土保持学报, 2002, 16(2): 29-32, 79-79. 


\section{ACTA ECOLOGICA SINICA Vol.33, No.19 Oct.,2013(Semimonthly) CONTENTS}

A review of ecosystem services and research perspectives

MA Fengjiao,LIU Jintong, A. Egrinya Eneji (5963)

Sexual interference in non-human primates

YANG Bin, WANG Chengliang, JI Weihong, et al (5973)

Density-dependent effect on reproduction of rodents : a review …............. HAN Qunhua, GUO Cong, ZHANG Meiwen (5981)

Proximate and ultimate determinants of food chain length ............................ WANG Yuyu, XU Jun, LEI Guangchun (5990)

Mechanism of biological control to plant diseases using arbuscular mycorrhizal fungi

LUO Qiaoyu, WANG Xiaojuan, LI Yuanyuan, et al (5997)

Advances in effects of conservation tillage on soil organic carbon and nitrogen

XUE Jianfu, ZHAO Xin, Shadrack Batsile Dikgwatlhe, et al (6006)

Habitat selection of the pre-released giant panda in Wolong Nature Reserve

ZHANG Mingchun, HUANG Yan, LI Desheng, et al (6014)

Activity rhythm and behavioral time budgets of wild Reeves's Pheasant (Syrmaticus reevesii) using infrared camera …................

ZHAO Yuze, WANG Zhichen, XU Jiliang, et al (6021)

The energy budget of tree sparrows Passer montanus in wind different speed and duration

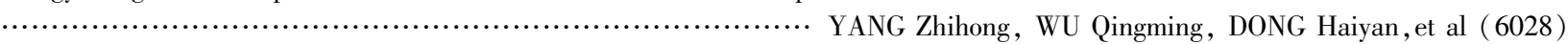

Nest site characteristics of Petaurista caniceps in Baima Snow Mountain Nature Reserve

LI Yanhong, GUAN Jinke, LI Dayong, HU Jie (6035)

Effects of habitat fragmentation on the genetic diversity of Pachycondyla luteipes on islands in the Thousand Island Lake, East

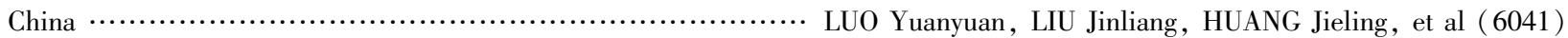

The molecular genetic relationship between the pollinators of Ficus pumila var. pumila and Ficus pumila var. awkeotsang ..............

WU Wenshan, CHEN Youling, SUN Lingli, et al (6049)

The genetic evolutionary relationships of two Eupristina species on Ficus altissima

............................................................ CHEN Youling, SUN Lingli, WU Leilei, et al (6058)

Metal uptake and root morphological changes for two varieties of Salix integra under cadmium stress

WANG Shufeng, SHI Xiang, SUN Haijing, et al (6065)

Effects of phthalic acid on seed germination, membrane lipid peroxidation and osmoregulation substance of radish seedlings ......................................................... YANG Yanjie, WANG Xiaowei, ZHAO Kang, et al (6074)

The morphological and physiological responses of Tamarix ramosissima seedling to different irrigation methods in the extremely arid area

MA Xiaodong, WANG Minghui, LI Weihong, et al (6081)

Response characteristics of photosynthetic and physiological parameters in Ziziphus jujuba var. spinosus seedling leaves to soil

water in sand habitat formed from seashells …................. WANG Rongrong, XIA Jiangbao, YANG Jihua, et al (6088)

Effects of ceramsite mulching on soil water content, photosynthetic physiological characteristics and growth of plants …...............

TAN Xuehong, GUO Xiaoping, ZHAO Tingning (6097)

Dynamics of tannin concentration and nutrient resorption for branchlets of Casuarina equisetifolia plantations at different ages .........

YE Gongfu, ZHANG Shangju, ZHANG Lihua, et al (6107)

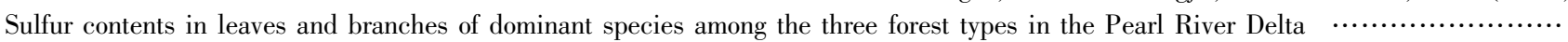

PEI Nancai, CHEN Bufeng, ZOU Zhijin, et al (6114)

Impacts of arbuscular mycorrhizal fungi and phosphorus on growth dynamics of Bauhinia faberi seedlings

SONG Chengjun, QU Laiye, MA Keming, et al (6121)

Characteristics of ion accumulation and seed germination for seeds from plants cultured at different concentrations of nitrate nitrogen and salinity

ZHOU Jiachao, FU Tingting, ZHAO Weiwei, et al (6129)

Physio-ecological effects of endophyte infection on the host grass with elevated $\mathrm{CO}_{2}$

Effects of pretreatment on germination of Typha domingensis and Phragmites australis

SHI Zhibing, ZHOU Yong, LI Xia, et al (6135)

MENG Huan, WANG Xuehong, TONG Shouzheng, et al (6142)

Transfer characteristics of cadmium from soil to Salix $\times$ aureo-pendula ….. ZHANG Wen, WEI Hong, SUN Xiaocan, et al (6147) Effect of Close-to-Nature management on the natural regeneration and species diversity in a masson pine plantation

LUO Yinghua, SUN Dongjing, LIN Jianyong, et al (6154)

Population dynamics and seed banks of the threatened seagrass Halophila beccarii in Pearl Bay, Guangxi

QIU Guanglong, FAN Hangqing, LI Zongshan, et al (6163)

Effects of biological crusts on dew deposition and evaporation in the Southern Edge of the Mu Us Sandy Land, Northern China ...... , Z

Life history characteristics and spatial distribution of Populus pruinosa population at the upper reaches of Tarim River $\cdots . . . . . . . . . . .$. .

Interactive effects of short-term nitrogen enrichment and simulated grazing on ecosystem respiration in an alpine meadow on the Tibetan Plateau ZONG Ning, SHI Peili, JIANG Jing, et al (6191) 
The correlation between soil water salinity and plant community distribution under micro-topography in Songnen Plain , W

Comparison of TSP, $\mathrm{PM}_{2.5}$ and their water-soluble ions from both inside and outside of Dafushan forest park in Guangzhou

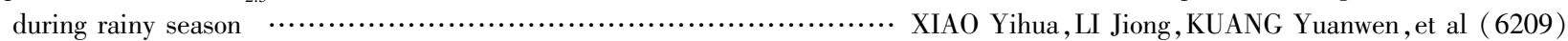

Fish community ecology in rocky reef habitat of $\mathrm{Ma}^{\prime}$ an Archipelago II . Spatio-temporal patterns of community structure

WANG Zhenhua, ZHAO Jing, WANG Kai, et al (6218)

Interannual variation in the population dynamics of snailfish Liparis tanakae in the Yellow Sea

CHEN Yunlong, SHAN Xiujuan, ZHOU Zhipeng, et al (6227)

Spatial and temporal variation of soil macro-fauna community structure in three temperate forests

... LI Na, ZHANG Xueping, ZHANG Limin (6236)

Community structure and species biodiversity of fig wasps in syconia of Ficus superba Miq. var. japonica Miq. in Fuzhou

CHEN Youling, CHEN Xiaoqian, WU Wenshan, et al (6246)

Marine ecological capital: valuation methods of marine ecosystem services …. CHEN Shang, REN Dachuan, XIA Tao, et al (6254)

Geomorphologic regionalization of China aimed at construction of nature reserve system ….......... GUO Ziliang, CUI Guofa (6264)

Impact of ecological vegetation construction on the landscape pattern of a Loess Plateau Watershed ....

YI Yang, XIN Zhongbao, QIN Yunbin, et al (6277)

Spatial heterogeneity of soil moisture across a cropland-grassland mosaic: a case study for agro-pastural transition in north of Chin

WANG Hongmei, WANG Zhongliang, WANG Kun, et al (6287)

The regional diversity of changes in growing duration of spring wheat and its correlation with climatic adaptation in Northern

China

Response of soil physical-chemical properties to rocky desertification succession in South China Karst ................................

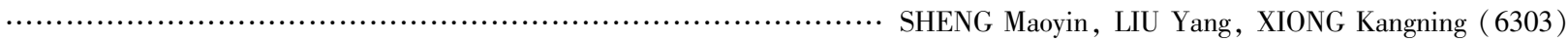

Prediction of the effects of climate change on the potential distribution of mire in Northeastern China

HE Wei, BU Rencang, LIU Hongjuan, et al (6314)

Soil nitrogen mineralization and associated temperature sensitivity of different Inner Mongolian grasslands

ZHU Jianxing, WANG Qiufeng, HE Nianpeng, et al (6320)

Effects of land use on soil nutrient in oasis-desert ecotone in the middle reach of the Heihe River

MA Zhimin, LÜ Yihe, SUN Feixiang, et al (6328)

Assessment on heavy metal pollution status in paddy soils in the northern Chengdu Plain and their potential ecological risk

QIN Yusheng, YU Hua, FENG Wenqiang, et al (6335)

Relationship between the temporal-spatial distribution of longline fishing grounds of yellowfin tuna (Thunnus albacares) and the thermocline characteristics in the Central Atlantic Ocean …......... YANG Shenglong, MA Junjie,ZHANG Yu, et al (6345)

Biological nitrogen fixation in the upper water column in the south Taiwan Strait during summer 2011

torage and drivers of forests carbon on the Beichangshan Island of Miaodao Archipelago

LIN Feng, CHEN Min, YANG Weifeng, et al (6354)

SHI Honghua, WANG Xiaoli, WANG Ai, et al (6363)

Impact of changes in vegetation types on soil $\mathrm{C}$ mineralization and associated temperature sensitivity in the Changbai Mountain

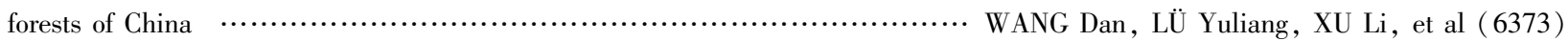

Analysis of relationship between genetic structure of Chinese Pine and mountain barriers

MENG Xiangxiang, DI Xiaoyan, WANG Mengben, et al (6382)

Soil organic carbon interpolation based on auxiliary environmental covariates:a case study at small watershed scale in Loess Hilly

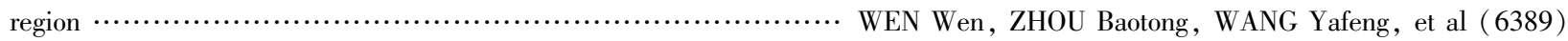

Eco-management benefit analysis of industrial resources from life cycle perspective: a case study of a virtual symbiosis network .

The game analysis between poverty and environment in ecologically fragile zones $\cdots$ QI Xinhua, YE Shilin, CHENG Yu, et al (6411)

The coupling development of economy and environment under the background of World Expo in Shanghai 


\section{《生态学报》2013 年征订启事}

《生态学报》是由中国科学技术协会主管, 中国生态学学会、中国科学院生态环境研究中心主办的生态学 高级专业学术期刊,创刊于 1981 年,报道生态学领域前沿理论和原始创新性研究成果。坚持“百花齐放,百家 争鸣” 的方针, 依靠和团结广大生态学科研工作者, 探索生态学奥秘, 为生态学基础理论研究搭建交流平台, 促进生态学研究深人发展, 为我国培养和造就生态学科研人才和知识创新服务、为国民经济建设和发展服务。

《生态学报》主要报道生态学及各分支学科的重要基础理论和应用研究的原始创新性科研成果。特别欢 迎能反映现代生态学发展方向的优秀综述性文章; 研究简报; 生态学新理论、新方法、新技术介绍; 新书评价和 学术、科研动态及开放实验室介绍等。

《生态学报》为半月刊,大 16 开本, 300 页, 国内定价 90 元/册, 全年定价 2160 元。

国内邮发代号: 82-7,国外邮发代号: M670

标准刊号:ISSN 1000-0933 CN 11-2031/Q

全国各地邮局均可订阅，也可直接与编辑部联系购买。欢迎广大科技工作者、科研单位、高等院校、图书 馆等订阅。

通讯地址: 100085 北京海淀区双清路 18 号 电话: (010)62941099; 62843362

E-mail: shengtaixuebao@ rcees.ac.cn网址: www.ecologica.cn

本期责任副主编 陈利顶 编辑部主任 孔红梅 执行编辑 刘天星 段 靖

\author{
生 态 学 报 \\ (SHENGTAI XUEBAO) \\ (半月刊 1981 年 3 月创刊)
}

第 33 卷 第 19 期 (2013 年 10 月)

\section{ACTA ECOLOGICA SINICA}

( Semimonthly, Started in 1981)

Vol. 33 No. 19 (October, 2013)

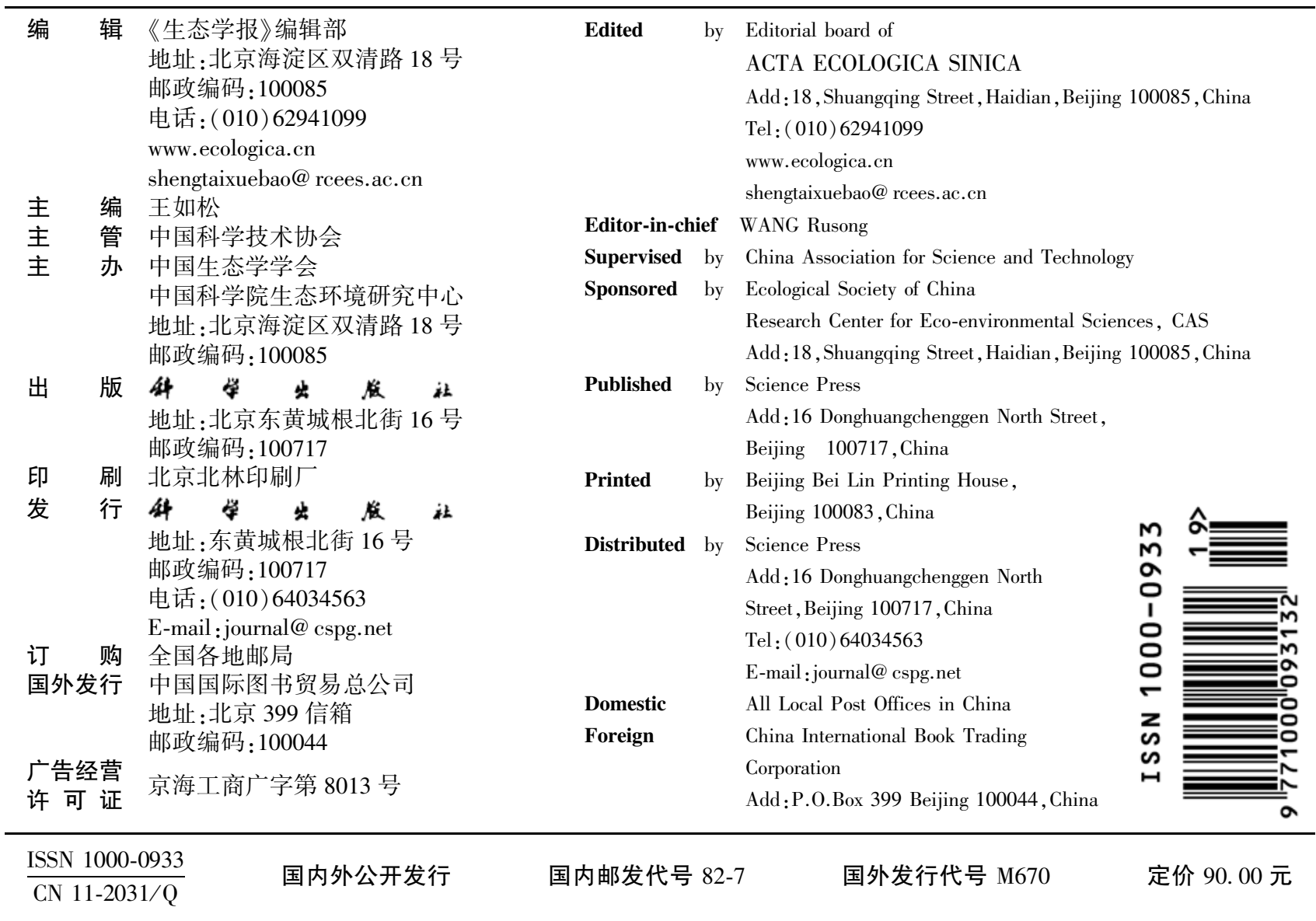

